\title{
ROZPOZNAWALNOŚĆ MAREK OFICJALNYCH SPONSORÓW I AMBUSH MARKETERÓW PODCZAS XXII ZIMOWYCH IGRZYSK OLIMPIJSKICH W SOCZI
}

\begin{abstract}
Rozpoznawalność marki sponsora jest nie tylko miarą efektywności sponsoringu sportowego, ale także ważnym celem działań zintegrowanej komunikacji marketingowej. Istotnym zagrożeniem tej komunikacji jest zjawisko ambush marketingu, które w ostatnich latach stało się problemem dla organizatorów imprez sportowych i sponsorów. Celem artykułu jest analiza i ocena rozpoznawalności marek oficjalnych partnerów i marek niebędących oficjalnymi sponsorami XXII Zimowych Igrzysk Olimpijskich w Soczi. W projekcie badawczym wykorzystano analizę danych wtórnych oraz dokonano monitoringu przekazów medialnych w okresie styczeń-marzec 2014 r. Badanie sondażowe zrealizowano 1-16 marca 2014 r. na celowej próbie 194 osób. W części empirycznej pracy dokonano charakterystyki programu sponsorskiego oraz zidentyfikowano kampanie promocyjne ambusherów podczas igrzysk. Wykazano, że oficjalni sponsorzy wydarzenia uzyskali istotnie statystycznie niższe wskaźniki rozpoznawalności (TOM, UBA i ABA) niż ambush marketerzy. Analiza rozpoznawalności poszczególnych marek pokazuje, że wśród najczęściej wskazywanych marek liderem w rankingu jest odzieżowa marka 4F. Ambush marketing stanowi zatem zagrożenie dla współczesnego sponsoringu dużych imprez sportowych. Dla organizatorów rekomenduje się wprowadzenie akcji edukacyjnych wśród konsumentów przed każdą dużą imprezą sportową mających na celu wyjaśnienie istoty ambush marketingu oraz zagrożeń, jakie niosą za sobą takie działania. Przedsiębiorstwa biorące udział w programach sponsorskich dużych imprez sportowych powinny zaś zintensyfikować działania promocyjne skierowane do grupy docelowej, aby podkreślić zaangażowanie i istniejące powiązanie sponsora $\mathrm{z}$ danym wydarzeniem.

Słowa kluczowe: marketing sportowy, sponsoring, ambush marketing, event sportowy, igrzyska olimpijskie, Soczi
\end{abstract}

\section{WPROWADZENIE}

Sponsoring działań sportowych, artystycznych czy edukacyjnych stał się narzędziem komunikacji marketingowej o zadziwiającym rozwoju marketingowym w ciagu ostatnich trzech dziesięcioleci, ponieważ oferuje szansę dotarcia do odbiorców w chaotycznym środowisku medialnym ${ }^{2}$. Umożliwia także rozwinięcie strategii pozycjonowania i zarządzania marką przez powiązanie $\mathrm{z}$ wydarzeniami o określonym statusie i wartości ${ }^{3}$. Mimo

\footnotetext{
${ }^{1}$ Dr Monika Piątkowska, Zakład Organizacji i Historii Kultury Fizycznej, Akademia Wychowania Fizycznego Józefa Piłsudskiego w Warszawie; ul. Marymoncka 34, 00-968 Warszawa, email: monika.piatkowska@awf.edu.pl

2 J. Crompton, Sponsorship ambushing in sport, „Managing Leisure” 2004/9, s. 1-12; T. Meenaghan, Ambush marketing: Corporate strategy and consumer reaction, „Psychology and Marketing” 1998/15, s. 305-322; J.A. Tripodi, M. Sutherland, Ambush marketing - "An Olympic event”, ,The Journal of Brand Management” 2000/7, s. 412-422.

${ }^{3}$ P. O’Sullivan, P. Murphy, Ambush marketing: The ethical issues, „Psychology and Marketing” 1998/15, s. 349-366.
} 
wszechobecnego kryzysu gospodarczego ta dynamika zmian utrzymuje się nieustannie na wysokim poziomie - wysokość światowych wydatków na cele sponsorskie wzrosła od dwóch miliardów dolarów w roku $1984^{4}$ do prognozowanych ponad pięćdziesięciu trzech miliardów dolarów w 2013 r.5. Należy podkreślić, że to właśnie sport stanowi główny segment rynku sponsorskiego, stanowiąc niemalże 70\% jego całości. Sponsoring stał się zatem integralną częścią mainstreamu komunikacyjnego ze względu na odgrywanie istotnej roli we wspieraniu działań organizacji mających na celu osiaganie własnych celów marketingowych.

Z kolei wciąż toczą się dyskusje nad wartością sponsoringu jako skutecznego środka promocyjnego ${ }^{6}$. Po pierwsze, ważną kwestią jest, czy znaczne nakłady sponsorskie w połączeniu $\mathrm{z}$ działalnością marketingową wokół największych imprez sportowych nie prowadzą do ich przekomercjalizowania. Po drugie, rosnące zróżnicowanie w określaniu sponsorów oficjalnych powoduje niezrozumienie w oczach konsumentów, co prowadzi do problemów z identyfikacją roli poszczególnych firm. Po trzecie, nie tylko główni sponsorzy, posiadający wyłączne prawa do wykorzystania marki danego wydarzenia, ale także inni przedsiębiorcy chcą skorzystać z pozytywnych skojarzeń, jakie wywołuje impreza, oraz ze skupionej na wydarzeniu uwagi mediów. Rośnie liczba przedsiębiorstw, które bez ponoszenia stosownych opłat licencyjnych, a tym samym bez posiadania oficjalnych praw, znajdują innowacyjne sposoby powiązania swojej marki z danym wydarzeniem, stosując tak zwany ambush marketing ${ }^{7}$.

\section{ISTOTA ZJAWISKA AMBUSH MARKETINGU}

Do pierwszych świadomych działań w zakresie ambush marketingu doszło podczas XXIII Letnich Igrzysk Olimpijskich w Los Angeles w roku 1984, w wyniku zmian wprowadzonych przez Międzynarodowy Komitet Olimpijski (MKOl) dotyczących uregulowania kwestii związanych ze sponsoringiem ${ }^{8}$. Wcześniej rynek sponsorski igrzysk olimpijskich był otwarty, co oznaczało, że każdy przedsiębiorca, który wyraził chęć wsparcia finansowego igrzysk olimpijskich i wniósł odpowiednią opłatę z tego tytułu, mógł zostać „oficjalnym” sponsorem. W rezultacie Igrzyska Olimpijskie w Montrealu w 1976 r. zgromadziły aż 628 sponsorów, co skutkowało zamieszaniem w rozpoznawaniu sponsorów „oficjalnych”, a tym samym deprecjacji znaku i symbolu olimpijskiego, wartości tytułu sponsora oraz świadomości widzów co do oficjalnych sponsorów wydarzenia?. W celu zapewnienia większych korzyści finansowych zarówno sponsorom, jak i organizatorom MKOl zdecydował udzielać wyłącznych praw swoim partnerom i wprowadził trzy kategorie (sponsorzy oficjalni, dostawcy, licencjobiorcy) oraz - co istotne - ograniczył liczbę sponsorów dla każdej kategorii. Pod względem korzyści finansowych strategia ta okazała się bardzo skuteczna - uzyskano wtedy bardzo wysoki przychód, i to bez wkładu ze strony sektora publicznego. Wprowadzenie ograniczenia nadały większą rangę firmom

\footnotetext{
${ }^{4}$ T. Meenaghan, Sponsorship - legitimising the medium, „European Journal of Marketing” 1991/25, s. 5-10.

${ }^{5}$ Sponsorship Outlook: Spending Increase Is Double-edged Sword, IEG 2013.

${ }^{6}$ D. Shani, D.M. Sandler, Ambush marketing: Is confusion to blame for the flickering of the flame?, „Psychology and Marketing" 1998/15, s. 367-383.

7 J.P. Graham, Ambush marketing, ,Sport Marketing Quarterly” 1997/6, s. 10-13.

${ }^{8}$ D. Shani, D.M. Sandler, op. cit., s. 367-383.

${ }^{9}$ A. Mikołajczyk, Ambush marketing na międzynarodowych imprezach sportowych, „Studia Gdańskie” 2009/VI, s. $244-258$.
} 
mającym status sponsora, a tym samym podniosły wartość i znaczenie sponsoringu. Jednakże narzucone prawo „wyłączności” spowodowało rozpoczęcie praktyk ambush marketingu.

W literaturze przedmiotu ambush marketing jest definiowany jako ,zaplanowana kampania marketingowa danej firmy przez pośrednie powiązanie jej i marki z konkretnym wydarzeniem sportowym w celu zdobycia pewnego stopnia rozpoznawalności i korzyści, jakie normalnie przysługują sponsorom oficjalnym"10. Burton i Chadwick podkreślają długofalowy aspekt tej taktyki: „Ambush marketing podstępny jest formą marketingu strategicznego, który ma na celu uzyskanie korzyści ze świadomości, uwagi, dobrej woli i innych, uzyskiwanych poprzez skojarzenie z wydarzeniem lub własnością, bez oficjalnego lub bezpośredniego związku z tym wydarzeniem lub własnością"11. Ambush marketing należy postrzegać zatem jako próbę wytworzenia bezpośredniego, ale co ważniejsze, także pośredniego skojarzenia z miejscem rozgrywania zawodów czy ich uczestnikami, bez ich zgody i oficjalnego przekazania praw.

Coraz liczniejsza grupa podmiotów angażuje się w ambush marketing ze względu na niemożność zaangażowania olbrzymich nakładów finansowych czy rzeczowych pozwalających na uzyskanie miana oficjalnego sponsora lub też nie mogą wejść w związek z danym wydarzeniem sportowym z powodu wyłącznych lub długoterminowych kontraktów zawartych z konkurencją ${ }^{12}$. Należy zaznaczyć, że przedsiębiorstwa stosujące praktyki ambush marketingu z reguły postępują według litery prawa - nie uciekają się do bezprawnego użycia znaku, symbolu czy nazwy wydarzenia, gdyż w większości wypadków nie podają się za oficjalnego sponsora ${ }^{13}$. Ambush marketing stał się istotnym problemem nie tylko dla organizatorów dużych imprez sportowych i posiadaczy praw, ale także dla przedsiębiorców, którzy nabywają prawa oficjalnych sponsorów, gdyż mają znaczący wpływ na wskaźniki ich rozpoznawalności ${ }^{14}$.

Dotychczas podjęto liczne próby oceny wpływu ambush marketingu na rozpoznawanie i zapamiętywanie sponsorów przez konsumentów ${ }^{15}$. Autorzy wskazują, że konsumenci

${ }^{10}$ T. Sporek, Sponsoring sportu w warunkach globalizacji. Dylematy $i$ wyzwania, Difin, Warszawa 2007, s. 176.

${ }^{11}$ N. Burton, S. Chadwick, Ambush Marketing in Sport: An Assessment of Implications and Management Strategies, The CIBS Working Paper Series 2008/3, Centre for International Business of Sport, Coventry University, s. 2.

${ }^{12}$ E.C. Schwarz, S.A. Hall, S. Shibli, Sport Facility Operations Management: A Global Perspective, Butterworth-Heinemann, Oxford 2010, s. 148.

${ }^{13}$ A. Mikołajczyk, op cit., s. 245.

${ }^{14}$ N. Burton, S. Chadwick, op cit., s. 3.

${ }^{15}$ T. Meenaghan, op cit., s. 305-322; D. Shani, D.M. Sandler, op. cit., s. 367-383; G. Nufer, A. Bühler, How effective is the sponsorship of global sports events? A comparison of the FIFA World Cups in 2006 and 1998 , „International Journal of Sports Marketing and Sponsorship” 2010/11, s. 303-319, J. Hoek, 'Ring Ring': Visual Pun or Passing Off?: An Examination of Theoretical and Research Issues Arising from Ambush Marketing, ,Asia-Australia Marketing Journal” 1997/5, s. 33-43; S. McKelvey, D.M. Sandler, K. Snyder, Sport Participant Attitudes Toward Ambush Marketing: An Exploratory Study of ING New York City Marathon Runners, ,Sport Marketing Quarterly” 2012/21, s. 7-18; T. Bettina Cornwell, I. Maignan, R. Irwin, Long-term Recall of Sponsorship Sources: An Empirical Investigation of Stadium and Sport Cafe Audiences, „AsiaAustralia Marketing Journal" 1997/5, s. 45-57; G. Nufer, Sponsoring the FIFA Football World Cup: The good, the bad and the surprising, ,Journal of Sponsorship” 2009/2, s. 241-249; G.V. Johar, M.T. Pham, K.L. Wakefield, How event sponsors are really identified: A (baseball) field analysis, „Journal of Advertising Research" 2006/46, s. 183-198; L. Pitt, M. Parent, P. Berthon, P.G. Steyn, Event sponsorship and ambush marketing: Lessons from the Beijing Olympics, „Business Horizons” 2010/53, s. 281-290; R. Grohs, U. Wagner, S. Vsetecka, Assessing the Effectiveness of Sport Sponsorships - An Empirical Examination, „Schmalenbach Business Review (SBR)" 2004/56, s. 119-138; S.R. McDaniel, L. Kinney, The implications of recency and gender effects in consumer response to ambush marketing, „Psychology and Marketing” 1998/15, s. 385-403; 
mają znaczne problemy w identyfikacji przedsiębiorstw o statusie sponsora oficjalnego danego wydarzenia i odróżnieniu ich od przedsiębiorstw stosujących praktyki ambush marketingu. Wyniki badań pochodzące z różnych krajów wskazują jednomyślnie, że kampanie marketingu podstępnego są niezwykle skuteczne. Konsumenci widowisk sportowych mają problem ze wskazaniem sponsorów lub - co gorsza - wymieniają firmy, które w żaden sposób nie mają powiązania z daną imprezą. Oficjalni i potencjalni sponsorzy powoli zaczynają kwestionować opłacalność tego typu inwestycji.

W pracy podjęto próbę dokonania charakterystyki programu sponsorskiego oraz identyfikacji praktyk ambush marketingu podczas XXII Zimowych Igrzysk Olimpijskich w Soczi. Celem artykułu jest analiza i ocena rozpoznawalności marek oficjalnych partnerów i marek niebędących oficjalnymi sponsorami XXII Zimowych Igrzysk Olimpijskich w Soczi.

Postawiono następujące hipotezy badawcze:

1. Zjawisko ambush marketingu występowało podczas XXII Zimowych Igrzysk Olimpijskich w Soczi.

2. Marki oficjalnych sponsorów XXII Zimowych Igrzysk Olimpijskich w Soczi są bardziej rozpoznawalne niż marki przedsiębiorstw stosujących praktyki ambush marketingu w badanej grupie.

\section{ZAŁOŻENIA METODOLOGICZNE BADAŃ WŁASNYCH}

\subsection{Metody zbierania danych}

W projekcie badawczym wykorzystano analizę danych wtórnych, czyli oficjalnej strony internetowej Igrzysk w Soczi (www.sochi2014.com) oraz witryn internetowych sponsorów wydarzenia. Dokonano monitoringu przekazów medialnych - transmisji relacji, kampanii promocyjnych pomiędzy relacjami i w ich trakcie, przekazów reklamowych w internecie, prasie itp. w okresie styczeń-marzec 2014 r. W analizie i ocenie rozpoznawalności marek oficjalnych sponsorów i marek niebędących oficjalnymi sponsorem XXII Zimowych Igrzysk Olimpijskich w Soczi posłużono się badaniem sondażowym, które zrealizowano 1-16 marca 2014 r., czyli 7 dni po ceremonii zamknięcia igrzysk.

\subsection{Metody analizy danych}

W analizie rozpoznawalności marek oficjalnych sponsorów i przedsiębiorstw stosujących praktyk ambush marketingu zastosowano dwa podstawowe wskaźniki komunikacji marketingowej służące do pomiaru stopnia zapamiętywania marek przez konsumentów, a zatem pokazujące stopień znajomości danej marki w populacji: spontaniczną świadomość marki (UBA, Unaided Brand Awareness), wyróżniając również pierwszą wymienianą markę (TOM, Top of Mind) oraz wspomaganą świadomość marki (ABA, Aided Brand Awareness $)^{16}$.

M.R. Lyberger, L. McCarthy, An assessment of consumer knowledge of, interest in, and perceptions of ambush marketing strategies, „Sport Marketing Quarterly” 2001/10, s. 130-137; S.R. McDaniel, L. Kinney, Ambush marketing revisited: an experimental study of perceived sponsorship effects on brand awareness, attitude towards the brand and purchase intention, „Journal of Promotion Management” 1996/3, s. 141-167; H. Preuss, Economics of Staging the Olympic. The comparisons of the Games 1972-2008, Edward Elgar, Cheltenham 2004; B. Séguin, M. Lyberger, N.J. O'Reilly, L. McCarthy, Internationalising ambush marketing: a comparative study, ,International Journal of Sports Marketing \& Sponsorship” 2005/6, s. 216-230.

${ }^{16}$ R. Kozielski, J. Pogorzelski, M. Dziekoński, Komunikacja marketingowa., [w:] Wskaźniki marketingowe, red. R. Kozielski, Wolters Kluwer Polska Sp. z o.o., Warszawa 2011, s. 325-454. 
Obliczenia statystyczne przeprowadzono z wykorzystaniem pakietu komputerowego IBM $^{\circledR}$ SPSS $^{\circledR}$ Statistics w wersji 21 . W celu zweryfikowania istotnych statystycznie różnic między przyjętymi wskaźnikami rozpoznawalności oficjalnych sponsorów a podmiotami, które zastosowały praktyki ambush marketingu podczas wydarzenia, wśród badanych konsumentów przeprowadzono testy niezależności $\mathrm{Chi}^{2}$. W ocenie istotności efektów przyjęto poziom istotności $\mathrm{p}=0,05$.

\subsection{Material}

Badanie sondażowe przeprowadzono na celowej próbie 194 osób. Na grupę badanych osób składali się studenci Akademii Wychowania Fizycznego Józefa Piłsudskiego w Warszawie, Wyższej Szkoły Kultury Fizycznej i Turystyki im. Haliny Konopackiej w Pruszkowie oraz Wyższej Szkoły Turystyki i Języków Obcych w Warszawie. Badaną grupę stanowiły studentki $(n=82)$ i studenci $(n=112)$ kierunków związanych ze sportem: turystyka i rekreacja $(n=88)$, wychowanie fizyczne $(n=51)$ oraz sport $(n=55)$. W większości były to osoby młode w wieku 20-24 lat (89,2\%). W tabeli 1 przedstawiono charakterystykę badanej populacji.

Tabela 1. Charakterystyka badanej populacji

Table 1. Characteristics of the studied population

\begin{tabular}{lcc}
\hline \multicolumn{1}{c}{ Czynniki } & $\mathbf{n}=\mathbf{1 9 4}$ \\
\hline Płeć & $\mathrm{n}$ & $(\%)$ \\
Mężczyźni & 82 & 57,7 \\
Kobiety & & 42,3 \\
Wiek & 173 & \\
20-24 lat & 16 & 89,2 \\
25-29 lat & 5 & 8,2 \\
> 30 lat & & 2,5 \\
Stopień studiów & 155 & \\
Licencjackie/inżynierskie & 39 & 79,9 \\
Magisterskie & & 20,1 \\
Kierunek studiów & 88 & \\
Turystyka i rekreacja & 51 & 45,4 \\
Wychowanie fizyczne & 55 & 26,3 \\
Sport & & 28,4 \\
Miejsce zamieszkania & 25 & \\
Wieś & 15 & 12,9 \\
Miasto do 20 tys. & 24 & 7,7 \\
Miasto 21-50 tys. & 17 & 12,4 \\
Miasto 51-100 tys. & 4 & 8,8 \\
Miasto 101-200 tys. & 10 & 2,1 \\
Miasto 201-500 tys. & 99 & 5,2 \\
Miasto > 500 tys. & & 51,0 \\
\hline
\end{tabular}

Źródło: badanie własne. 


\section{WYNIKI BADAŃ - AMBUSH MARKETING PODCZAS XXII ZIMOWYCH IGRZYSK OLIMPIJSKICH W SOCZI}

\subsection{Charakterystyka programu sponsorskiego podczas XXII Zimowych Igrzysk Olimpijskich w Soczi}

Igrzyska olimpijskie są jedną z najbardziej skutecznych platform komunikacji marketingowej na świecie, pozwalającą dotrzeć jednocześnie do miliardów ludzi w ponad 200 krajach i terytoriach na całym świecie. Wsparcie ze strony środowiska biznesu ma kluczowe znaczenie dla inscenizacji igrzysk i działalności każdej organizacji mającej na celu promowanie idei ruchu olimpijskiego. Przychody generowane przez sponsorów stanowią ponad $40 \%$ przychodów MKOl-u. Partnerzy zapewniają niezbędne usługi oraz wsparcie techniczne produktów dla całej rodziny olimpijskiej. Z kolei igrzyska dają przedsiębiorcom ogromną możliwość rozwijania innowacyjnych sposobów budowania swojej marki, zwiększenia sprzedaży, komunikowania się ze społeczeństwem, budowania długotrwałych relacji z klientami oraz wzmacniania pozytywnego wizerunku firmy w skali globalnej.

Globalny program sponsorski przygotowany na XXII Zimowe Igrzyska Olimpijskie w Soczi objął trzy grupy podmiotów:

- $\quad$ Światowych partnerów (Worldwide Olympic Partners) biorących udział w TOP programie (The Olympic Partner Programme);

- $\quad$ narodowych partnerów (National Partners Sochi 2014);

- $\quad$ partnerów (Partners).

Udział w programie TOP zapewnia każdemu partnerowi wyłączne globalne prawa marketingowe w ramach wyznaczonych kategorii produktu lub usługi przez cztery lata (Olympic quadrennium). Program TOP IX XXII Zimowych Igrzysk Olimpijskich w Soczi obejmował 10 podmiotów:

- $\quad$ Atos - światowy partner technologii informacyjnej;

- $\quad$ Coca-Cola - wyłączny dostawca napojów bezalkoholowych;

- $\quad$ Dow - dostawca rozwiązań technologicznych;

- $\quad$ GE - wyłączny dostawca innowacyjnych produktów i usług, które są integralną częścią inscenizacji igrzysk olimpijskich;

- $\quad$ McDonald's - oficjalna restauracja Igrzysk w Soczi;

- $\quad$ Omega - wyłączny dostawca usług związanych z pomiarem wyników sportowych;

- $\quad$ Panasonic - wyłączny dostawca sprzętu audiowizualnego;

- $\quad$ Procter \& Gamble - patron kampanii „Wspieramy mamy”;

- $\quad$ Samsung - wyłączny dostawca sprzętu bezprzewodowego;

- $\quad$ Visa - wyłączny dostawca usług płatniczych.

Oprócz głównych, ogólnoświatowych sponsorów, źródłem zarobków jest sponsoring umożliwiający korzystanie ze znaku olimpijskiego, jednak ograniczony terytorialnie do jednego kraju - gospodarza igrzysk. W Soczi do tego grona należały następujące firmy:

- $\quad$ Aerofłot - rosyjskie linie lotnicze;

- $\quad$ Bosco - producent ubrań sportowych, główny partner Rosyjskiego Komitetu Olimpijskiego i dostawca strojów dla olimpijskiej reprezentacji Rosji;

- $\quad$ MegaFon - dostawca usług telekomunikacyjnych i teleinformatycznych;

- $\quad$ Koleje Rosyjskie, RŻD - operator rosyjskiej sieci kolejowej; 

petrochemicznej;

Rosnieft (Роснефть) - rosyjski państwowy koncern działający w branży

- $\quad$ Rostelecom - techniczny partner Igrzysk w Soczi;

- $\quad$ Sberbank - rosyjski bank;

- $\quad$ Volkswagen Group Rus - producent floty samochodowej.

W trzeciej grupie partnerów znaleźli się Ingosstrakh - lider rosyjskiego rynku ubezpieczeń, PricewaterhouseCoopers $(\mathrm{PwC})$ - dostawca usług w zakresie doradztwa podatkowego, prawnego i biznesowego, oraz Sportlotto (Спортлото) - operator gier liczbowych i loterii pieniężnych w Rosji.

\subsection{Identyfikacja zjawiska ambush marketingu podczas XXII Zimowych Igrzysk Olimpijskich w Soczi}

Podczas XXII Zimowych Igrzysk Olimpijskich w Soczi zidentyfikowano przypadki ambush marketingu zarówno na międzynarodowej, jak i polskiej arenie. Jednym z ciekawych przykładów jest kampania promocyjna producenta zapalniczek - amerykańskiej firmy Zippo Manufacturing Company ${ }^{17}$. Kampania ruszyła 6 października 2013 r. zaraz po tym, jak olimpijski znicz niesiony przez byłego pływaka Shavarsha Karapetyana zgasł na ulicach Moskwy i został podpalony przez policjanta zapalniczką Zippo. Firma natychmiast wykorzystała ten incydent i zamieściła w mediach społecznościowych zdjęcie $\mathrm{z}$ hashtagiem \#ZippoSavesOlympics (Zippo ratuje igrzyska).

Reakcja MKOl-u była natychmiastowa. Zippo zostało zmuszone do zakończenia kampanii, gdyż w ten sposób nielegalnie wykorzystywało skojarzenie z igrzyskami, nie mając statusu oficjalnego sponsora. W miejscu zdjęcia ukazującego Shavarsha Karapetyana firma zamieściła nową fotografię podkreślającą związek $\mathrm{z}$ tą imprezą sportową, tym samym wywołując jeszcze większy szum medialny wokół swojej marki.

Kolejny przykład to kampania sieci amerykańskich restauracji Subway, która od lat w swoich przekazach reklamowych wykorzystuje skojarzenia z igrzyskami olimpijskimi. Przy okazji Soczi firma postanowiła wykorzystać wizerunek byłego panczenisty Apolo Ohno i aktualnej uczestniczki igrzysk snowbordzistki Torah Bright ${ }^{18}$. Reklama była emitowana przed okresem zakazu pokazywania reklam nie-sponsorów (tzw. blackout period), czyli od 30 stycznia do 26 lutego 2014 r. Cała sceneria przekazu oraz hasło przewodnie (Subway® Official Training Restaurant of Athletes Everywhere - Subway Oficjalną Restauracją Sportowców na całym świecie) ewidentnie nawiązywały do Igrzysk w Soczi i były atakiem na bezpośredniego konkurenta - firmę McDonald's - oficjalnego sponsora igrzysk.

Praktyka ambush marketingu została również zastosowana przez sieć Starbucks, która umieściła swoja kawiarnię w zakazanej strefie (tzw. blackout zone) w centrum medialnym NBC (http://consumerist.com/2014/02/21/theres-a-secret-sochi-starbucks-for-nbc-staffonly-and-its-on-lockdown/). Na tym obszarze powinny być sprzedawane jedynie produkty oficjalnych sponsorów, w tym przypadku sieci McDonald's. Starbucks obsługiwał ponad 2500 pracowników NBC, którzy byli dokładnie poinstruowani o zakazie wynoszenia kubków Starbucks poza kawiarnię.

\footnotetext{
${ }^{17}$ D. Mackay, Zippo drop cheeky Olympic Torch Facebook campaign after accused of ambush marketing, 2013; http://www.insidethegames.biz. (10.06.2014)

${ }^{18}$ S. Joseph, Top 5 Sochi 2014 ambush marketing stunts 2014; http://www.marketingweek.com (10.06.2014).
} 
W branży samochodowej na praktykę ambush marketingu odważyła się marka Audi, nawiązując w reklamie swym znakiem towarowym do pięciu kół olimpijskich. Bardzo sprytne zastąpienie jednego koła i umiejscowienie hasła „Kiedy cztery kółka to wszystko, czego potrzebujesz" (When four rings is all you need) nie jest bezpośrednim naruszeniem praw marketingowych MKOl-u.

Przypadki ambush marketingu pojawiły się także w branży odzieżowej. Amerykańska marka American Apparel w obronie praw homoseksualistów w Rosji wypuściła serię ubrań P6. Kampania nawiązywała do fundamentalnych zasad olimpizmu umieszczonych w Karcie Olimpijskiej: „Uprawianie sportu jest prawem człowieka. Każdy musi mieć możliwość uprawiania sportu bez jakiejkolwiek dyskryminacji [...]. Każda forma dyskryminacji w stosunku do kraju lub osoby ze względu na rasę, wyznanie religijne, poglądy polityczne, płeć lub jakiegokolwiek innego względu jest niemożliwa do pogodzenia z przynależnością do Ruchu Olimpijskiego" "19. Firma wykorzystała wizerunek Mike’a Janyka - narciarza alpejskiego będącego uczestnikiem Igrzysk w Soczi i dwóch byłych olimpijczyków Grega Louganisa i Camerona Mylera.

Na Igrzyskach w Sochi pojawił się również światowy lider praktyk ambush marketingu - firma Nike. Nike emitowało kampanię promocyjną Play Russian specjalnie przygotowaną na rynek rosyjski. Spoty reklamowe wykorzystujące wizerunek rosyjskich gwiazd olimpijskich - hokeisty Alexandra Ovechkina, snowbordzisty Deniasa Leontyeva i łyżwiarki Adeliny Sotnikovej - miały wspierać Rosjan w walce o medale. Kampania zachęcała również widzów do zamieszczania filmów uwieczniających ich ulubione sportowe chwile z oznaczającym je hashtagiem \#playrussian i tym samym promowania marki w mediach społecznościowych.

Na polskiej arenie również pojawiło się kilka przypadków praktyk ambush marketingu. Większość z nich dotyczy sponsoringu subkategorii związanej z imprezą sportową, czyli sponsoringu reprezentacji Polski podczas Igrzysk w Soczi. Sponsorem strategicznym Polskiej Reprezentacji Olimpijskiej Soczi 2014 został Kulczyk Holding i Kulczyk Investments. Prezes firmy, Jan Kulczyk, mocno nagłaśniał ten fakt w mediach. Dodatkowo prezes wystappił na Gali Olimpijskiej w Warszawie, gdzie wręczał polskim medalistom Igrzysk w Soczi sztabki złota.

Sponsorem generalnym polskiej reprezentacji było Lotto, marka Totalizatora Sportowego. Współpraca Totalizatora Sportowego z Polskim Komitetem Olimpijskim jest długoletnia i konsekwentna - sponsoring Polskiej Reprezentacji Olimpijskiej trwa już od 1994 r. Totalizator Sportowy wspierał polskich olimpijczyków na igrzyskach w Lillehammer (1994), Atlancie (1996), Salt Lake City (2002), Atenach (2004), Pekinie (2008), w Vancouver (2010) oraz w Londynie (2012). Marka Lotto bardzo intensywnie wykorzystała czas igrzysk na liczne kampanie promocyjne wykorzystujące wizerunek polskich olimpijczyków z Soczi w telewizji, radio, prasie, jak również w internecie.

Wśród ambusherów na polskiej arenie pojawiło się Tyskie, marka Kompanii Piwowarskiej, która w ostatnich latach bardzo silnie nawiązuje do wielu imprez sportowych, nie mając statusu oficjalnego sponsora. Podobnie jak poprzednie przypadki, Tyskie zaangażowało się w sponsoring polskiej reprezentacji. Celem akcji promocyjnej przygotowanej przez Tyskie było zaktywizowanie Polaków do czynnego wspierania olimpijczyków. Kibice byli zachęcani do nagrywania krótkich filmów ze swoim skokiem lub podskokiem

\footnotetext{
${ }^{19}$ MKOl, Karta Olimpijska, 2007.
} 
w dowolnej technice. Następnie filmy były zamieszczane na Youtube.pl i dodawane do galerii na stronie www.skoczkibicować.pl. Zwycięskie skoki stały się częścią telewizyjnych spotów reklamowych marki Tyskie. Spoty z udziałem laureatów konkursu był emitowane w podczas zawodów indywidualnych i drużynowych. Kampania promocyjna ruszyła stosunkowo późno, gdyż tydzień po ceremonii otwarcia Igrzysk w Soczi, jednakże firmie udało się osiagnnąć zamierzony efekt.

Ostatni przykład ambush marketingu to sukces $4 \mathrm{~F}$, marki OTCF - producenta odzieży sportowej, która była sponsorem Kolekcji Olimpijskiej. Firma dostarczyła komplety ponad czterdziestu elementów ubioru dla każdego uczestnika Igrzysk w Soczi. Już w listopadzie 2013 r. zorganizowano premierowy pokaz całej kolekcji, na który zaproszono ponad czterystu gości ze świata sportu, biznesu, mediów i kultury ${ }^{20}$. Dzięki udziałowi celebrytów wydarzenie to zostało bardzo nagłośnione w mediach. Dodatkowo 4F wykorzystała wizerunek Kamila Stocha w swej komunikacji.

\subsection{Rozpoznawalność marek oficjalnych sponsorów i przedsiębiorstw stosujących praktyki ambush marketingu podczas XXII Zimowych Igrzysk Olimpijskich w Soczi}

W całej badanej próbie zaobserwowano istotne statystycznie różnice w rozpoznawalności badanych podmiotów według wskaźnika pierwszej wymienionej marki (TOM) $\left(\mathrm{Chi}^{2}=111,8 ; \mathrm{p}<0,05\right)$. Wskaźnik rozpoznawalności oficjalnych sponsorów wydarzenia wśród badanych konsumentów jest znacznie niższy $(13,4 \%)$ niż podmiotów, które zastosowały praktyki ambush marketingu $(39,7 \%)\left(\mathrm{Chi}^{2}=35,6 ; \mathrm{p}<0,05\right)$. Należy jednak podkreślić, że tak wysoki wskaźnik TOM w wypadku ambusherów (39,7\%) wynika w głównej mierze z wysokiego odsetka osób, które wymieniły markę 4F jako podmiot angażujący się w sponsoring Igrzysk w Soczi (34,5\%). W badanej grupie respondenci ograniczyli się do wymienienia jedynie sponsorów z grupy TOP programme. Marki partnerów narodowych i partnerów igrzysk nie zostały w ogóle zapamiętane. Najprawdopodobniej można to wytłumaczyć tym, że wśród tych sponsorów znalazły się marki rosyjskie, które były nieznane respondentom. Zupełnie innych wyników można by się spodziewać w przypadku przeprowadzenia badań wśród respondentów rosyjskich. Warto zwrócić również uwagę na stosunkowo wysoki odsetek osób, które nie były w stanie wymienić żadnej marki sponsora. Co czwarty badany $(41,2 \%)$ nie wiedział lub też nie pamiętał, kto był oficjalnym sponsorem analizowanego wydarzenia.

Analiza rozpoznawalności poszczególnych marek pokazuje, że wśród najczęściej wskazywanych marek liderem w rankingu jest odzieżowa marka 4F (34,5\%), która była sponsorem Kolekcji Olimpijskiej w Soczi (rys. 1). Marka 4F wyprzedziła wszystkich oficjalnych sponsorów igrzysk, będąc dla Polaków marką najbardziej kojarzoną z imprezą. Tak wysoki wskaźnik TOM potwierdza niebywały sukces tej marki. Rozpoznawalność marek oficjalnych sponsorów była stosunkowo niska i utrzymywała się mniej więcej na tym samym poziomie, co innych podmiotów stosujących praktyki ambush marketingu. Niektórzy oficjalni sponsorzy, nawet $\mathrm{z}$ grupy TOP, zupełnie nie zaistnieli $\mathrm{w}$ trakcie igrzysk w świadomości kibiców. Przykładowo Atos, Dow, GE, Panasonic czy Visa uzyskali wskaźnik TOM na poziomie $0 \%$.

\footnotetext{
${ }^{20}$ OTCF, Z klasq i na sportowo - pokaz Zimowej Kolekcji Olimpijskiej Soczi 2014, materiały prasowe 2013, http://4f.com.pl. (10.06.2014).
} 


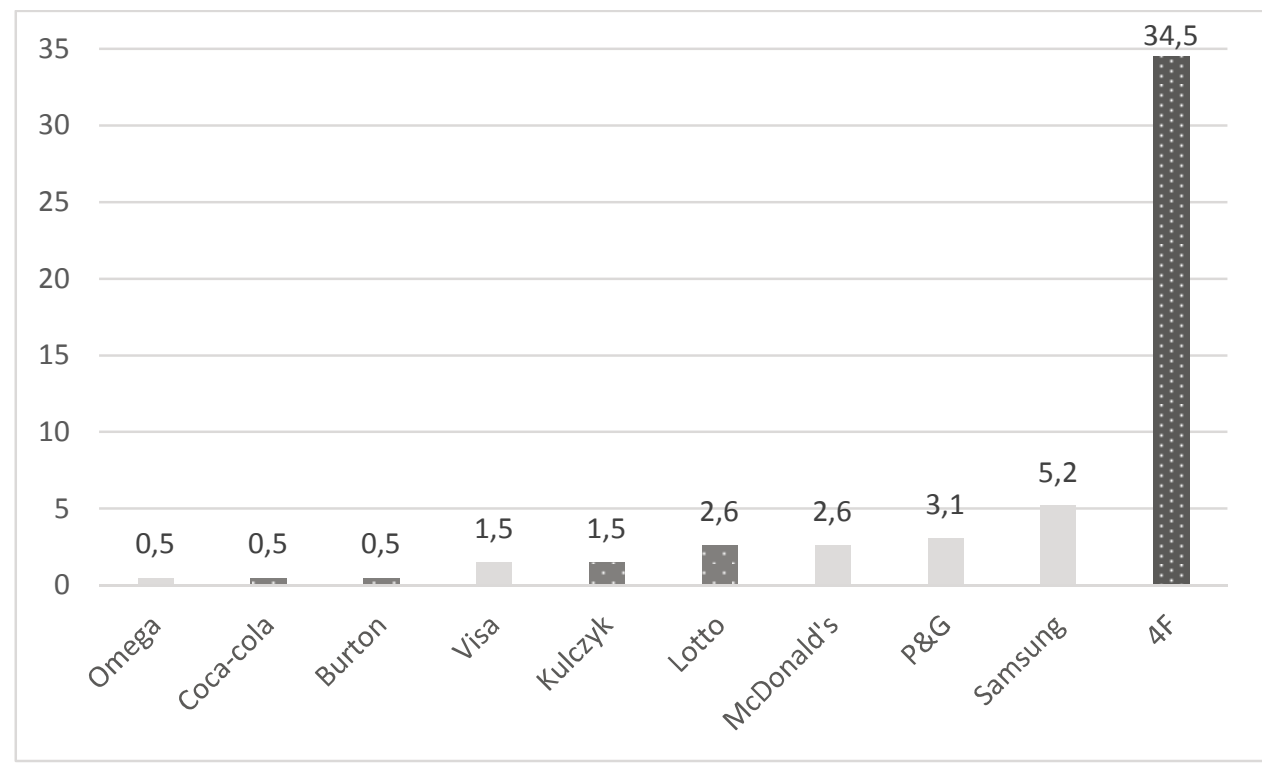

\section{Oficjalni sponsorzy; $\quad \because \because$ Ambusherzy}

Rys. 1. Ranking dziesięciu najczęściej wskazywanych marek postrzeganych jako oficjalni sponsorzy XXII Zimowych Igrzysk Olimpijskich w Soczi wg wskaźnika TOM (\%)

Fig. 1. TOM rate (\%) ranking of top 10 brands considered as the Olympic official sponsors Źródło: badanie własne

Najczęściej ze względu na założenia metodologiczne wysokość wskaźnika wspomaganej świadomości marki - ABA - jest znacznie wyższa od wskaźników UBA i TOM. Z przeprowadzonych badań wynika, że odsetki wskaźnika ABA są znacznie niższe od wskaźników UBA i TOM. Należy jednak podkreślić, że w tabeli 2 przedstawiono wielkość wskaźników spontanicznej (UBA) i wspomaganej (ABA) świadomości marek podmiotów angażujących się w kampanie promocyjne podczas Igrzysk w Soczi wśród respondentów, którzy wskazali tylko sponsorów lub tylko ambusherów. W kategorii „,sponsorzy + ambusherzy" ujęto odpowiedzi, które zawierały zarówno marki jednej, jak i drugiej grupy. Celem zastosowania tych właśnie wskaźników była zatem próba odpowiedzi na pytanie, czy konsumenci są w stanie odróżnić podmioty angażujące się w oficjalny program sponsorski Igrzysk w Soczi od podmiotów podszywających się pod oficjalnych partnerów wydarzenia.

Podobnie jak w wypadku analizy pierwszej wymienionej marki, wyniki spontanicznej świadomości marki przemawiają na korzyść ambusherów $(26,8 \%)$ w porównaniu ze sponsorami $(6,2 \%)$ (tab. 2). Potwierdza to także wynik przeprowadzonej analizy statystycznej $\left(\mathrm{Chi}^{2}=36,9 ; \mathrm{p}<0,05\right)$. Jedna piąta badanych $(22,7 \%)$ nie była $\mathrm{w}$ stanie rozróżnić od siebie tych dwóch grup.

W wypadku wspomaganej świadomości marki wyniki przedstawiają się podobnie w porównaniu ze wskaźnikiem spontanicznej świadomości marki (tab. 2). Znacznie korzystniej wypadają podmioty stosujące praktyki ambush marketingu. Respondenci istotnie 
rzadziej wskazywali markę oficjalnego sponsora wydarzenia niż ambushera $\left(\mathrm{Chi}^{2}=18,3\right.$; $\mathrm{p}<0,01)$. Jednakże należy zwrócić uwagę na bardzo wysoki odsetek osób $(70,6 \%)$, które z podanej listy zawierającej różne marki nie wskazały poprawnie oficjalnych partnerów imprezy, a zatem nie są świadomi, kto poniósł ogromne nakłady finansowe umożliwiające legalne korzystanie z przyznanych praw.

Tabela 2. Spontaniczna i wspomagana świadomość marek podmiotów angażujących się w kampanie promocyjne podczas XXII Zimowych Igrzysk Olimpijskich w Soczi

Table 2. UBA and ABA of brands running promotional campaigns during the Olympic Games in Sochi

\begin{tabular}{lcc} 
Podmioty & $\begin{array}{c}\text { UBA } \\
(\boldsymbol{\%})\end{array}$ & $\begin{array}{c}\text { ABA } \\
(\boldsymbol{\%})\end{array}$ \\
\hline Sponsorzy & $6,2^{*}$ & $6,2^{*}$ \\
Ambusherzy & 26,8 & 20,6 \\
Sponsorzy + am- & 22,7 & 70,6 \\
busherzy & & 0 \\
Inne & 3,1 & 0 \\
* istotnie różne $(\mathrm{p}<0,05)$ & - sponsorzy vs ambusherzy, sponsorzy + ambusherzy \\
Źródło: badanie własne. &
\end{tabular}

Na rysunku 2 przedstawiono spontaniczną i wspomaganą świadomość dziesięciu najczęściej wskazywanych marek postrzeganych przez badaną grupę jako oficjalni sponsorzy Igrzysk w Soczi. Niezmiennym liderem tego rankingu pozostaje marka 4F. Ze względu na wysokie wskaźniki spontanicznej świadomości marki wysoko w rankingu znalazły się podmioty, które były oficjalnymi sponsorami, a nie zostały wskazane przez respondentów jako pierwsza marka (TOM): Atos (41,2\%) i Aerofłot (22,7\%). Równie wysokie miejsce zajął Adidas, który nie miał statusu sponsora ani nie angażował się w akcje marketingu podstępnego. Można tłumaczyć tym, że Adidas bardzo często angażuje się w sponsoring sportowy głównie w piłce nożnej i rzeczywiście jest kojarzony imprezami sportowymi.

W wypadku wspomaganej świadomości marek nadal liderem tego rankingu pozostaje marka 4F (75,3\%). Bardzo wysoki wynik osiagnął oficjalny sponsor Samsung. Kolejne miejsca należą do marek, które nie angażowały się w ambush marketing: Adidas i Red Bull. 


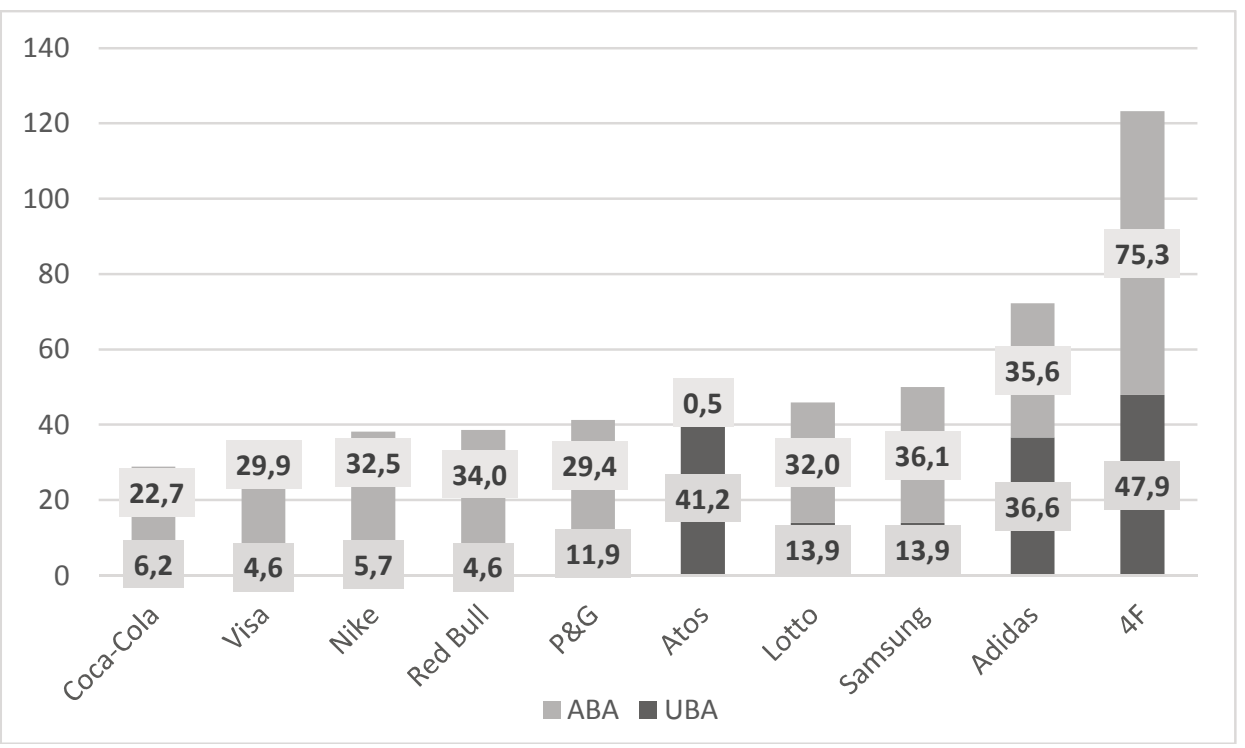

Rys. 2. Spontaniczna (UBA, Unaided Brand Awareness) i wspomagana (ABA, Aided Brand Awareness) świadomość marek postrzeganych jako oficjalni sponsorzy Igrzysk w Soczi (\%).

Fig. 2. Unaided (UBA) and aided (ABA) awareness of brands perceived as the Olympic official sponsors $(\%)$.

Źródło: badanie własne.

Podsumowując, jeśli uwzględnić wskaźniki rozpoznawalności, to do wygranych marek podczas Igrzysk w Soczi należą ambusher - 4F (UBA = 75,3\%; ABA = 47,9\%), marka niebędąca oficjalnym sponsorem ani ambusherem - Adidas (UBA $=36,6 \%$; $\mathrm{ABA}=$ $35,6 \%)$ i oficjalny sponsor - Samsung $(\mathrm{UBA}=13,9 \%$; $\mathrm{ABA}=36,1 \%)$.

\section{DYSKUSJA}

XXII Zimowe Igrzyska Olimpijskie w Soczi odbyły się 7-23 lutego 2014 r. Uczestniczyło w nich ponad 2850 sportowców z 88 krajów, zdobywając rekordową liczbę 98 medali. Impreza była transmitowana przez 464 stacje telewizyjne. Cztery lata temu w Vancouver było ich zaledwie 240. Tak szeroki zasięg zapewnił oglądalność (co najmniej jednominutową 1-min) rzędu 2 miliardów ludzi na całym świecie, o 200 milionów więcej niż w Vancouver (http://www.sochi2014.com). Nic zatem zaskakującego, że takie wydarzenie przykuło uwagę licznych światowych i rosyjskich marek, które walczyły o status oficjalnego sponsora wydarzenia, ponosząc przy tym ogromne nakłady finansowe. Według raportu podsumowującego Igrzyska z Soczi, dochód z marketingowego programu przekroczył 1,3 miliarda amerykańskich dolarów.

Na podstawie przeprowadzanych badań wykazano, że podczas tego wydarzenia zacięta walka nie toczyła się wyłącznie na boisku sportowym, ale również między dużymi korporacjami międzynarodowymi, które starały się wypromować swoje marki w skali globalnej. Odnotowano przypadki kampanii promocyjnych nawiązujących do imprezy, przeprowadzonych przez podmioty, które nie miały statusu oficjalnego sponsora. 
Liczba wyróżnionych praktyk ambush marketingu nie jest zatrważająca. Najprawdopodobniej nie wszystkie takie studia przypadku zostały zidentyfikowane. Pewnym ograniczeniem projektu jest brak analizy monitoringu przekazów medialnych prowadzonych w języku rosyjskim - transmisji meczów, kampanii promocyjnych pomiędzy meczami i w ich trakcie, przekazów reklamowych w internecie, prasie itp. Ze względu na ograniczenia językowe autorki było to niemożliwe. Jednakże nawet te nieliczne przypadki miały ogromny wpływ na wyniki rozpoznawalności podmiotów angażujących się w kampanie promocyjne przed Igrzyskami w Soczi, w ich trakcie i po nich. W wyniku przeprowadzonej analizy okazało się, że podczas Igrzysk w Soczi rozpoznawalność sponsorów była niezadowalająca. Znacznie wyższe wskaźniki rozpoznawalności (TOM, UBA i ABA) uzyskały marki podmiotów wykorzystujących skojarzenia z wydarzeniem sportowym, a nieponoszące nakładów finansowych na kontrakty sponsorskie - ambusherów. Jest to jednocześnie sprzeczne z badaniami Cromptona, który zauważa, że intensywność prowadzonych kampanii reklamowych marek sponsorów i ich aktualna popularność mają wpływ na rezultaty istnienia marki w świadomości konsumentó $w^{21}$. W rankingu dziesięciu najczęściej wskazywanych marek postrzeganych jako oficjalni sponsorzy Igrzysk według wskaźnika TOM znalazło się wprawdzie pięć marek, jednak ich rozpoznawalność jest niższa niż ambusherów. Najwyższe wskaźniki TOM osiągnęły następujące firmy: Samsung $(5,2 \%)$, Procter \& Gamble $(3,1 \%)$, McDonald's $(2,6 \%)$, Visa $(1,5 \%)$ i Omega $(0,5 \%)$.

Są to znacznie niższe wyniki niż te otrzymane z raportu amerykańskich badań online firmy YouGov ${ }^{22}$. Na pierwszych trzech miejscach w rankingu rozpoznawalności znaleźli się oficjalni sponsorzy. Prawie jedna trzecia Amerykanów (32\%) poprawnie wskazała McDonald's jako oficjalnego sponsora Igrzysk w Soczi, 29\% rozpoznało Coca-Colę, a $26 \%$ - Visę. Co piąty badany (21\%) uznał, że Nike był sponsorem zimowych zmagań, podczas gdy marka była jedynie partnerem reprezentacji Stanów Zjednoczonych. Stosunkowo wysokie wyniki osiągnęli również Red Bull (17\%) i Adidas (10\%). Są odsetki wskazań zbliżone do Procter \& Gamble (10\%) i Samsunga (9\%) - partnerów igrzysk.

Według analiz amerykańskiej firmy Global Language Monitor przeprowadzonych na podstawie monitoringu internetu, blogosfery, mediów drukowanych i elektronicznych najbardziej rozpoznawalną marką Igrzysk został Red Bull (kojarzony ze sponsoringiem sportów ekstremalnych), wyprzedzając oficjalnych sponsorów Procter \& Gamble oraz Samsunga (http://www.languagemonitor.com/category/ambush-marketing-2/).

W niniejszym projekcie badawczym, jak wspomniano wcześniej, marki przedsiębiorstw stosujących praktyki ambush marketingu zostały znacznie lepiej rozpoznane niż oficjalnych sponsorów Igrzysk w Soczi. Należy jednak podkreślić, że tak wysoki wynik: TOM $=39,7 \%$ (ambusherzy) i 13,4\% (oficjalni sponsorzy) został osiągnięty dzięki tak naprawdę jednej marce - 4F (TOM = 34,5\%), która była sponsorem Olimpijskiej Kolekcji Soczi polskich sportowców. Marka była bardzo dobrze widoczna w mediach. Dodatkowo, cały pomysł został wzmocniony kampanią promocyjną, w której wykorzystano wizerunek Kamila Stocha, największej nadziei medalowej. Okazuje się, że przyniosło to marce wymierny wizerunkowy skutek.

\footnotetext{
${ }^{21} \mathrm{~J}$. Crompton, Conceptualization and alternate operationalizations of the measurement of sponsorship effectiveness in sport, "Leisure Studies" 23/3 (2004), s. 267-281.

${ }^{22}$ Z. Diaz, One Third Of Americans Correctly Identify McDonalds As Official Olympic Sponsor, 2014, http://research.yougov.com (10.06.2014).
} 
Otrzymane wyniki badań są zgodne z projektem Pit i in., którzy podczas XXIX Letnich Igrzysk Olimpijskich w 2008 roku w Pekinie udowodnili, że ambusher Li Ning (firma odzieżowa) zyskał znacznie wyższą rozpoznawalność niż oficjalny sponsor Adidas ${ }^{23}$. Wykorzystano wskaźnik rozpoznawalności wspomaganej. Poprawnie zostały rozpoznane trzy marki sponsora z czterech ujętych w badaniu - Air China $(57,1 \%)$, Tsingtao $(63,8 \%)$, Visa $(65,9 \%)$. Ostatnia marka sponsora, o którą pytano w badaniu to Adidas, którą wskazało $62,6 \%$ badanych i był to wynik o kilka punktów procentowych niższy od marki Li Ning, na którą przypadło $67,4 \%$ wskazań. Li Ning pokonała markę sponsora głównie ze względu na nietypową reklamę podczas ceremonii otwarcia igrzysk. Li Ning to chiński sportowiec, który po zakończeniu kariery został właścicielem firmy produkującej odzież sportową pod własnym nazwiskiem. W Pekinie zapalał znicz olimpijski, będąc ubranym w dres własnej marki z widocznym logo, które dostrzegła milionowa widownia przekazu telewizyjnego. Dzięki temu marka stała się bardzo rozpoznawalna, a wśród specjalistów do spraw marketingu mówiono o przypadku „Li Ning”. Podobnego fenomenu dokonała marka 4F podczas Igrzysk w Soczi, deklasując pozostałe firmy, które angażowały się w jakiekolwiek kampanie promocyjne podczas tej imprezy.

Relacja istnienia w świadomości odbiorcy sponsorów w stosunku do ambusherów była przedmiotem wielu badań także podczas innych wydarzeń sportowych. Najwięcej takich opracowań dotyczy ambush marketingu podczas igrzysk olimpijskich. Naukowcy zajmujący się eksploracją tego zjawiska dowodzą, że pojedynek pomiędzy sponsorami a niesponsorami nie zawsze wygrywają ci pierwsi. Na przykład Sandler i Shani pokazali, że dezorientacja konsumentów na temat tego, kto jest, a kto nie jest sponsorem Zimowych Igrzysk Olimpijskich w Kanadzie w 1998 roku była wysoka ${ }^{24}$. Tylko 20\% z wszystkich respondentów poprawnie rozpoznało sponsora w badaniu spontanicznej rozpoznawalności, a 39\% respondentów wskazało marki sponsora w badaniu wspomaganym.

Badania Séguin i in. przeprowadzone w 2000 roku podczas Igrzysk Olimpijskich w Sydney wśród respondentów trzech krajów - Kanady, Francji i Stanów Zjednoczonych dowodzą, że respondenci wszystkich państw mieli kłopoty z właściwym rozpoznaniem sponsora $^{25}$. Lista najbardziej rozpoznawanych marek wśród różnych narodowości znacząco się różni, a wskaźniki rozpoznawalności marek sponsorów w stosunku do ambusherów są na zbliżonym poziomie. Na przykład w tym badaniu wskaźnik wspomaganej rozpoznawalności marek sponsorów wyniósł wśród respondentów kanadyjskich, amerykańskich, francuskich odpowiednio: Coca-cola - 24\%, 25\%, 38\%; McDonald's - 21\%, 39\%, $11 \%$. W wypadku ambusherów wyniki przedstawiają się odpowiednio: Nike $-23 \%, 31 \%$, $31 \%$; Reebok $-10 \%, 3 \%$, brak danych. Badania Séguin i in. pokazują, że rozpoznawalność sponsorów i ambusherów jest zatem uwarunkowana kulturowo ${ }^{26}$. W każdym kraju osiągnięto nieco inne wyniki. Potwierdza to także wyniki otrzymane w niniejszym projekcie. Wśród polskich respondentów wygrała zdecydowanie polska marka - ambusher 4F, podczas gdy w badaniach amerykańskich najczęściej wskazywano marki amerykańskie. Respondenci mają zatem tendencję wybierania tych marek, które są im bliższe i bardziej

\footnotetext{
${ }^{23}$ L. Pitt, M. Parent, P. Berthon, P.G. Steyn, Event sponsorship and ambush marketing: Lessons from the Beijing Olympics, „Business Horizons”, 53/3 (2010), s. 281-290.

${ }^{24}$ D.M. Sandler, D. Shani, Olympic Sponsorship vs. 'Ambush' Marketing: Who Gets the Gold?, „Journal of Advertising Research" 1989/29, s. 9-14.

${ }^{25}$ B. Séguin, M. Lyberger, N.J. O'Reilly, L. McCarthy, op. cit., s. 216-230.

${ }^{26}$ Ibidem.
} 
znane. Naturalnie, aby udowodnić tę hipotezę, należałoby poprowadzić pogłębione badania na międzynarodowej próbie badawczej zróżnicowanej kulturowo.

Jednak nie zawsze działania ambusherów są aż tak skuteczne. Po zawodach FIFA World Cup 2006 Portlock i Rose dowiedli, że konsumenci doskonale rozpoznają sponsorów oraz że istnieje niewielka rozpoznawalność ambusherów ${ }^{27}$. W badaniu wykorzystano wskaźniki wspomaganej świadomości marki. Marki oficjalnych sponsorów zostały zdecydowanie lepiej rozpoznanie niż ich ambusherzy: Coca-Cola - 55,3\% (sponsor), podczas gdy Pepsi - 6,5\% (ambusher); Budweiser - 64,9\% (sponsor), a Calsberg - 9,6\% (ambusher); Adidas 43,3\% (sponsor) i Nike - 13,7\% (ambusher).

Badania przeprowadzone podczas tego samego wydarzenia przez Nufera pokazują, że ambush marketing występował, ale najwięksi oficjalni sponsorzy uzyskali zadowalającą rozpoznawalność wśród konsumentów, a tylko część firm sponsorów osiąnęła wynik niższy niż firmy niemające statusu oficjalnego sponsora wydarzenia ${ }^{28}$. Pierwsze cztery najwyższe wyniki rozpoznawalności (UBA) zdobyły firmy oficjalnych sponsorów: McDonald's - 59,5\%, Adidas - 51,9\%, Coca-cola - 46,6\%, Deutsche Telekom - 28,8\%. Kolejne trzy marki według rankingu UBA to ambusherzy: Nike $-20,2 \%$, Nutella $18,8 \%$, Puma - 17,8\%. W wypadku badań Grohs i in. przeprowadzonych po Alpine Ski World Championships w 2001 roku łączna rozpoznawalność ABA i UBA sponsorów była niezwykle wysoka ${ }^{29}$. Wskaźniki sponsorów wyglądały następująco: Milka - 86\%, Telekom Austria - 69\%, MW - 53\%, Tag Heuer - 36\%. Nieco inaczej wyglądają wyniki w niniejszej pracy, mimo że jedna marka zwyciężyła w walce o świadomość konsumenta w kategorii sponsora Igrzysk w Soczi, to jednak rozpoznawalność łączna sponsorów była znacznie niższa niż ambusherów.

\section{PODSUMOWANIE}

Podsumowując, ambush marketing w sporcie stanowi zagrożenie dla współczesnego sponsoringu dużych imprez sportowych. Mimo usilnych prób organizatorów (między innymi międzynarodowych federacji czy komitetów olimpijskich) oraz rządów państwgospodarzy do ograniczenia tego zjawiska poprzez implementację stosownych mechanizmów, coraz więcej przedsiębiorstw decyduje się w swoich kampaniach promocyjnych na wykorzystanie powiązania $z$ daną imprezą sportową bez ponoszenia opłat sponsorskich. Są to coraz bardziej innowacyjne i wyrafinowane działania, które najczęściej są zgodne $\mathrm{z}$ obowiązującą literą prawa. Takie praktyki, jak się okazuje, są również bardzo skuteczne.

Z kolei należy pamiętać, że sam tytuł oficjalnego sponsora imprezy sportowej jest niewystarczające dla zdobycia rozgłosu i miejsca w świadomości publicznej. Niezbędny jest zintegrowany program komunikacji marketingowej obejmujący każdy aspekt sponsoringu i zarządzania marką oraz określający kanały i metody komunikacji z otoczeniem, a także antycypujący potencjalne działania ambush marketingu konkurentów ${ }^{30}$.

\footnotetext{
${ }^{27}$ A. Portlock, S. Rose, Effects of ambush marketing: UK consumer brand recall and attitudes to official sponsors and non-sponsors associated with the FIFA World Cup 2006, „International Journal of Sports Marketing and Sponsorship" 2009/10, s. 271-286.

${ }^{28}$ G. Nufer, op. cit., s. 241-249.

${ }^{29}$ R. Grohs, U. Wagner, S. Vsetecka, op. cit., s. 119-138.

${ }^{30}$ A. Mikołajczyk, op cit., s. 257.
} 
Przeprowadzony projekt badawczy dotyczący ambush marktingu podczas XXII Zimowych Igrzysk Olimpijskich w Soczi pozwolił na wyciągnięcie następujących wniosków:

- Ambush marketing stał się nieodłączną częścią międzynarodowych imprez sportowych. Z tego względu konieczne jest prowadzenie ciąłych badań dotyczących rozpoznawalności marek oficjalnych sponsorów, by eliminować negatywne skutki zjawiska ambush marketingu.

- Opis zidentyfikowanych praktyk ambush marketingu oraz badania dotyczące rozpoznawalności podmiotów angażujących się w kampanie promocyjne podczas imprez sportowych mogą być pomocne w podnoszeniu świadomości konsumentów na temat zjawiska.

- Ze względu na znaczną dezorientację konsumentów w rozróżnieniu sponsorów i ambusherów zaleca się wprowadzenie akcji edukacyjnych wśród konsumentów przed każdą dużą imprezą sportową mających na celu wyjaśnienie istoty ambush marketingu oraz zagrożeń, jakie niosą ze sobą takie działania.

- Przedsiębiorstwa biorące udział w programach sponsorskich dużych imprez sportowych powinny zintensyfikować działania promocyjne skierowane do grupy docelowej, aby podkreślić zaangażowanie i istniejące powiązanie sponsora $\mathrm{z}$ danym wydarzeniem.

\section{LITERATURA}

[1] Bettina Cornwell T., Maignan I., Irwin R., Long-term Recall of Sponsorship Sources: An Empirical Investigation of Stadium and Sport Cafe Audiences, „Asia-Australia Marketing Journal” 5/1 (1997), s. 45-57, doi: http://dx.doi.org/10.1016/S1320-1646(97)70257-0.

[2] Burton N., Chadwick S., Ambush Marketing in Sport: An Assessment of Implications and Management Strategies, The CIBS Working Paper Series 2008/3, Centre for International Business of Sport, Coventry University.

[3] Crompton J., Conceptualization and alternate operationalizations of the measurement of sponsorship effectiveness in sport, „Leisure Studies” 23/3 (2004), s. 267-281.

[4] Crompton J., Sponsorship ambushing in sport, „Managing Leisure” 9/1 (2004), s. 1-12

[5] Diaz Z., One Third Of Americans Correctly Identify McDonalds As Official Olympic Sponsor, 2014, http://today.yougov.com/news/2014/02/04/one-third-americans-correctly-identifymcdonalds-o/.

[6] Graham J.P., Ambush marketing, ,Sport Marketing Quarterly” 6/1 (1997), s. 10-13.

[7] Grohs R., Wagner U., Vsetecka S. Assessing the Effectiveness of Sport Sponsorships - An Empirical Examination, „Schmalenbach Business Review” (SBR) 56/2 (2004), s. 119-138.

[8] Hoek J. 'Ring Ring': Visual Pun or Passing Off?: An Examination of Theoretical and Research Issues Arising from Ambush Marketing, „Asia-Australia Marketing Journal” 5/1 (1997), s. 33-43, doi: http://dx.doi.org/10.1016/S1320-1646(97)70256-9.

[9] IEG. 2013 Sponsorship Outlook: Spending Increase Is Double-edged Sword, 2013, http://www.sponsorship.com/iegsr/2013/01/07/2013-Sponsorship-Outlook--SpendingIncrease-Is-Dou.aspx.

[10] Johar G.V., Pham M.T., Wakefield K.L. How event sponsors are really identified: A (baseball) field analysis, ,Journal of Advertising Research” 46/2 (2006), s. 183-198

[11] Joseph S. Top 5 Sochi 2014 ambush marketing stunts, 2014, http://www.marketingweek.co. uk/sectors/sport/news/top-5-sochi-2014-ambush-marketing-stunts/4009557.article

[12] Kozielski R., Pogorzelski J., Dziekoński M., Komunikacja marketingowa, [w:] Wskaźniki marketingowe, red. R. Kozielski, Wolters Kluwer Polska Sp. z o.o., Warszawa 2011 , s. 325-454. 
[13] Lyberger M.R., McCarthy L., An assessment of consumer knowledge of, interest in, and perceptions of ambush marketing strategies, ,Sport Marketing Quarterly” 10/3 (2001), s. 130-137.

[14] Mackay D., Zippo drop cheeky Olympic Torch Facebook campaign after accused of ambush marketing, 2013, http://www.insidethegames.biz/olympics/winter-olympics/2014/1016390zippo-drop-cheeky-olympic-torch-facebook-campaign-after-accused-of-ambush-marketing.

[15] McDaniel S.R., Kinney L., Ambush marketing revisited: an experimental study of perceived sponsorship effects on brand awareness, attitude towards the brand and purchase intention, „Journal of Promotion Management” 3/1-2 (1996), s. 141-167.

[16] McDaniel S.R., Kinney L., The implications of recency and gender effects in consumer response to ambush marketing, ,Psychology and Marketing” 15/4 (1998), s. 385-403.

[17] McKelvey S., Sandler D.M., Snyder K., Sport Participant Attitudes Toward Ambush Marketing: An Exploratory Study of ING New York City Marathon Runners, ,Sport Marketing Quarterly" 21/1 (2012), s. 7-18.

[18] Meenaghan T., Sponsorship - legitimising the medium, „European Journal of Marketing” 25/11 (1991), 5-10.

[19] Meenaghan T., Ambush marketing: Corporate strategy and consumer reaction, „Psychology and Marketing" 15/4 (1998), s. 305-322.

[20] Mikołajczyk A., Ambush marketing na międzynarodowych imprezach sportowych, „Studia Gdańskie" 2009/VI, s. 44-258.

[21] MKO1, Karta Olimpijska, 2007, http://www.olimpijski.pl/files/Download/Karta_ olimpijska_PL.pdf.

[22] Nufer G., Sponsoring the FIFA Football World Cup: The good, the bad and the surprising, „Journal of Sponsorship” 2/3 (2009), s. 241-249.

[23] Nufer G., Bühler A., How effective is the sponsorship of global sports events? A comparison of the FIFA World Cups in 2006 and 1998, „International Journal of Sports Marketing and Sponsorship" 11/4 (2010), s. 303-319.

[24] O'Sullivan P., Murphy P., Ambush marketing: The ethical issues, „Psychology and Marketing" 15/4 (1998), s. 349-366.

[25] OTCF, Z klasq i na sportowo - pokaz Zimowej Kolekcji Olimpijskiej Soczi 2014, Materiały prasowe 2013; www.4f.com.pl.

[26] Pitt L., Parent M., Berthon P., Steyn P.G., Event sponsorship and ambush marketing: Lessons from the Beijing Olympics, „Business Horizons” 53/3 (2010), s. 281-290, http://dx.doi.org/10.1016/j.bushor.2010.01.002.

[27] Portlock A., Rose S., Effects of ambush marketing: UK consumer brand recall and attitudes to official sponsors and non-sponsors associated with the FIFA World Cup 2006, „International Journal of Sports Marketing and Sponsorship" 10/4 (2009), s. 271-286.

[28] Preuss, H., Economics of Staging the Olympic. The comparisons of the Games 1972-2008, Edward Elgar, Cheltenham 2004.

[29] Sandler D.M., Shani D., Olympic Sponsorship vs. 'Ambush' Marketing: Who Gets the Gold?, „Journal of Advertising Research” 29/4 (1989), s. 9-14.

[30] Schwarz E.C., Hall S.A., Shibli S., Sport Facility Operations Management: A Global Perspective, Butterworth-Heinemann, Oxford 2010.

[31] Séguin B., Lyberger M., O'Reilly N.J., McCarthy L., Internationalising ambush marketing: a comparative study, „International Journal of Sports Marketing \& Sponsorship” 6/4 (2005), s. $216-230$.

[32] Shani D., Sandler D.M., Ambush marketing: Is confusion to blame for the flickering of the flame?, „Psychology and Marketing” 15/4 (1998), s. 367-383.

[33] Sporek T., Sponsoring sportu $w$ warunkach globalizacji. Dylematy $i$ wyzwania. Difin, Warszawa 2007.

[34] Tripodi J.A., Sutherland M., Ambush marketing - “An Olympic event”, „The Journal of Brand Management" 7/6 (2000), s. 412-422. 


\section{BRAND RECOGNITION OF OFFICIAL SPONSORS AND AMBUSH MARKET- ERS DURING THE XXII OLYMPIC WINTER GAMES IN SOCHI}

Sponsor brand recognition is not only a measure of the effectiveness of sport sponsorship activities, but it is also an important objective of integrated communication marketing. It is significantly threatened by the phenomenon of ambush marketing, which in recent years has become a problem for the organizers and sponsors of sporting events. The aim of the paper is to analyze and evaluate brand recognition of the official sponsors and ambush marketers during the XXII Olympic Winter Games in Sochi. Secondary data analysis and media monitoring coverage between January-March 2014 were used in the project. Additionally, a target sample $(\mathrm{n}=194)$ of Polish students was surveyed between 1-16 March 2014. In the empirical part of the paper the characteristic of Olympic sponsorship programme was provided. Promotional campaigns of ambush marketers were identified. The analysis revealed that the official sponsors have obtained significantly lower rates of recognition (TOM, UBA and ABA) than the ambush marketers. Ambush marketing may be, therefore, regarded as a threat to the modern sponsorship of mega sport events. As for the organizers it is recommended to introduce educational campaigns among consumers before any large sporting event to clarify the essence of ambush marketing and the risks posed by such activities. Enterprises involved in the sponsorship programs of major sporting events should intensify the promotional campaigns directed to the target group in order to emphasize the commitment and the existing link of the sponsor with the event.

Keywords: sport marketing, sponsorship, ambush marketing, sport event, Olympic Games, Sochi

DOI: $10.7862 /$ rz.2014.mmr.53

Tekst złożono w redakcji: listopad 2014

Przyjęto do druku: grudzień 2014 